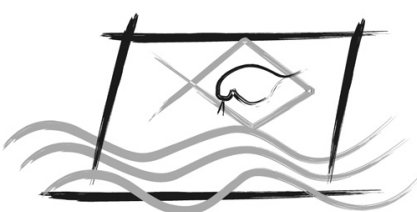

ECOTOX - BRASIL

\title{
Use of coal mining waste for river water treatment and evaluation of this process using physicochemical parameters and bioassays
}

\author{
M.S. Francisconil ; A. de Bona ${ }^{1}$; F.Z. Da Silveira ${ }^{1}$; R. Geremias ${ }^{2} \&$ C.T. Pich ${ }^{2}$ \\ ${ }^{1}$ Universidade do Extremo Sul Catarinense, Av. Universitária, 1105, CEP 88806-000, Criciúma, SC, Brazil. \\ ${ }^{2}$ Universidade Federal de Santa Catarina, Campus Araranguá, Rua Pedro João Pereira, 150, CEP 88900-000, \\ Araranguá, Santa Catarina, Brazil.
}

(Received December 21, 2012; Accept June 18, 2013)

\begin{abstract}
This work aimed to use calcinated coal mining waste to treat river water contaminated by residues derived from coal mines. Water samples from the Urussanga River (Urussanga, Santa Catarina state, Brazil) were collected. The pH values and the concentrations of aluminum, iron and manganese were determined before and after the treatment. Additionally, acute toxicity tests $\left(\mathrm{CL}_{50}\right)$ were carried out in the microcrustaceans Artemia sp. and Daphnia magna along with root growth inhibition tests of Allium cepa L. and plasmid DNA cleavage assays. The results demonstrate that the treatment resulted in an increase in the $\mathrm{pH}$ and an expressive removal of metals. It was observed that the untreated water caused significant toxicity in Artemia sp., Daphnia magna and Allium cepa L. as well as fostering damage to plasmid DNA. However, after the treatment was detected reduction of the toxicity. It was concluded that the calcinated coal mining waste can be used as alternative system for the treatment of waters affected by coal mining contaminants, while the bioassays consists of an excellent tool for the evaluation of this process.
\end{abstract}

Keywords: coal mining waste; river water treatment; physicochemical parameters; toxicity; bioassays

\section{INTRODUCTION}

Coal mining is one of the main economic activities of the southern region of the state of Santa Catarina, Brazil. However, it has provoked severe environmental problems, including the generation of effluents characterized by low $\mathrm{pH}$ values $(\mathrm{pH}<3.0)$ and high concentrations of metals such as iron, aluminum and manganese (Benassi et al., 2006). These contaminants may reach water sources and cause various toxic effects on biota.

Coal mining also generates large amounts of carbonouspyritic wastes which are often deposited in the environment inappropriately and not recovered economically (Blodau, 2006). These waste can alter the environment in a variety of ways which include the removal of vegetation cover, the reconfiguration of surface topography, visual impact, accelerated erosion, compromised soil quality, emission of gases and particles into the air, increased turbidity and siltation of water bodies, the generation of acid drainage, and the contamination of water resources (Bitar, 1997).

Metal oxides obtained from the calcination of waste mining coal have been used successfully as an alternative treatment of effluents generated in coal activity. These oxides are capable of acting as adsorbent of $\mathrm{H}_{3} \mathrm{O}^{+}$, thereby provoking a $\mathrm{pH}$ increase with subsequent precipitation and removal of the metals in solution (Geremias et al., 2008).

The treatment efficiency of different coal mining effluents using fisicochemical parameters like $\mathrm{pH}$, concentration of different metals ( $\mathrm{Al}, \mathrm{Fe}, \mathrm{Mn}, \mathrm{Cu}, \mathrm{Zn}, \mathrm{Ni}, \mathrm{Pb}, \mathrm{Cr}, \mathrm{Cd}$ i. e.) and sulfates among others has been described in the literature

*Corresponding author: Reginaldo Geremias; e-mail: reginaldogeremias@gmail.com 
(Netto et al., 2013; Bharti \& Banerjee, 2013; Madzivire et al., 2011).

Evaluations of the physicochemical parameters and bioassays significantly contribute to better evaluate the efficacy of treatment of waters with metal oxides.

Acute toxicity tests on microcrustaceans Artemia sp. and Daphnia magna have been used for the evaluation of deleterious effects on organisms exposed to environmental contaminants. Carrying out test on microcrustaceans has several advantages including the great reproductive potential of these animals, their easy acquisition on the market, easy maintenance in the laboratory, their easily hatched cysts and the easy reproducibility (Nunes et al., 2006; Martins et al., 2007; Pimentel et al., 2011).

Several studies have reported successfully using Allium cepa L. (onion) as a bioindicator for the ecotoxicological evaluation of environments contaminated by various classes of pollutants, including metals. Several parameters of phytotoxicity can be assessed, such as bioaccumulation of contaminants in different tissues (roots, leaves, bulbs,) root growth inhibition, genotoxicity and oxidative stress (Saurabh et al., 2005; Fatima \& Ahmad, 2006; Mitteregger-Júnior et al., 2006). A. cepa testing provides benefits such as sensitivity, reproducibility, short response time, need for low-volume samples of the contaminant, and low cost.

Measuring biomarkers of biochemical, physiological and morphological alteration has also been described as a tool for assessing the toxic potential of environmental contaminants (Burger et al., 2007). To this end, testing the cleavage of plasmid DNA in vitro can be indicated for the purpose of estimating the oxidative damage to genetic material (Sreedhara $\&$ Cowan, 2001).

In the present study proposed we used calcinated coal mining waste as an alternative treatment for rivers affected by coal mining and evaluated the effectiveness of such treatment by way of physicochemical parameters and toxicity tests in Artemia sp., Daphnia magna, Allium cepa L., as well as measurements of damage to plasmid DNA.

\section{MATERIALS AND METHODS}

\section{River water and coal mining waste}

Water samples $(20 \mathrm{~L}$ per point) were collected along the Urussanga River (Santa Catarina state, South Brazil) at three different points: Point 1 ( $28^{\circ} 30$ '33.8' S; 49 $18^{\circ}$ ' $53.9^{\prime}$ 'W) corresponds to the source of the river, where the economic activity of extraction and beneficiation of coal is quite intense; Point 2 ( $28^{\circ} 41$ ' $42.7^{\prime}$ ' $\mathrm{S}$; $49^{\circ} 10^{\prime} 21.5^{\prime}$ ' $\mathrm{W}$ ) is the intermediate part of the river; Point 3 ( $28^{\circ} 47^{\prime}$ '44.9' ' S; 49 $11^{\circ}$ ' 23.7' ' W) corresponds to the river's estuary. The $\mathrm{pH}$ of the samples was determined by potentiometry (Corning pHmeter, model $\mathrm{pH} /$ ion analyzer 350) and the concentrations of iron, aluminum and manganese by Flame Atomic Absorption Spectroscopy
- FAAS (Hitachi Spectrometer Z8230) (US EPA method 3005a). Carbonous-pyritic coal mining wastes (200 g) were collected from a carboniferous underground mining region of Criciúma (Santa Catarina state, South Brazil). For the calcination process, the coal mining waste was heated to 800 ${ }^{\circ} \mathrm{C}$ for $1 \mathrm{~h}$ in a muffle furnace. Preliminary calcination tests and thermogravimetric analysis showed that the temperature and heating time influence the removal of organic matter and the formation of metal oxides (results not shown). The characterization of the calcinated waste oxides was carried out through X-ray diffraction-XRD(Philips diffractometer X'pert). The XRD spectra were compared with those in the catalogs of the International Center for Diffraction Data (ICDD). The results showed the presence of mainly $\mathrm{SiO}_{2}, \mathrm{Al}_{2} \mathrm{O}_{3}$ and $\mathrm{Fe}_{2} \mathrm{O}$ in the calcinated waste (Geremias et al., 2008).

\section{River water treatment with calcinated coal mining wastes}

The river water samples were treated with calcinated coal mining (ratio of 1:25 w/v), in a batch system, in Erlenmeyer flasks under magnetic stirring (200 rpm) at room temperature $\left(22^{\circ} \mathrm{C} \pm 3^{\circ} \mathrm{C}\right)$ for $48 \mathrm{~h}$ (Geremias et al., 2008). After treatment, samples were filtrated. The $\mathrm{pH}$ in the treated water samples was determined by potentiometry and the concentrations of iron, aluminum and manganese were determined by FAAS.

\section{Artemia sp. acute toxicity test}

The acute toxicity test in Artemia sp. was performed according to Meyer et al. (1982) with some modifications. A saline solution was prepared with synthetic sea salt $(30 \mathrm{~g}$ $\mathrm{L}^{-1}$ ) and used as the incubation medium for Artemia sp. cysts. Young subjects (10 subjects) were exposed to untreated and treated water with calcinated waste, in multi-well plates with $2 \mathrm{~mL}$ of each concentration $(3.12,6.25,12.5,25,50$ and $100 \%)$ and the negative control $(0 \%)$, for $24 \mathrm{~h}$ in the dark at room temperature $\left(22^{\circ} \mathrm{C} \pm 3{ }^{\circ} \mathrm{C}\right)$. All samples were corrected to a $30 \mathrm{~g} \mathrm{~L}^{-1}$ concentration of synthetic sea salt. At the end of period of exposure, the number of dead organisms was observed and the median lethal concentration $\left(\mathrm{LC}_{50}\right)$ was determined by non-linear sigmoidal regression, applying the Boltzmann mathematical model, using the Origins program and expressed as a percentage (Hamilton et al., 1977).

\section{Daphnia magna acute toxicity test}

The acute toxicity test on Daphnia magna was performed in accordance with the Brazilian Association of Technical Standards-ABNT (ABNT, 1993), with some modifications. Ten young organisms ( $24 \mathrm{~h}$ old) were exposed to untreated water and treated water with calcinated waste, in becker botles with $25 \mathrm{~mL}$ of each concentration $(3.12,6.25,12.5,25,50$ and $100 \%)$ and the negative control $(0 \%)$ in the dark at room temperature $\left(22^{\circ} \mathrm{C} \pm 3^{\circ} \mathrm{C}\right)$. After $48 \mathrm{~h}$ of exposure, the number of dead organisms was observed and the lethal concentration for $50 \%\left(\mathrm{LC}_{50}\right)$ was determined by non-linear sigmoidal regression, applying the Boltzmann mathematical model, 
using the Origins ${ }^{\circledR}$ program and expressed as a percentage (Hamilton et al., 1977).

\section{Allium cepa L. sub-chronic toxicity assay}

The inhibition of root growth in Allium cepa L. was measured according to Bortolotto et al. (2009) with some modifications. Bulbs of Allium cepa L. used in the experiments were bought from local commercial source of organic products. Tree different groups were estabilshed and six bulbs were used in each group: group one (negative control), bulbs were incubated with commercial mineral wather; group two, bulbs were incubated with untreated water; group treee, bulbs were incubated with treated water. For the exposition $50 \mathrm{~mL}$ polyethylene tubes (Falcon) werre used and they were maintained for seven days at room temperature $\left(22{ }^{\circ} \mathrm{C} \pm 3{ }^{\circ} \mathrm{C}\right)$ in the dark. The experimental solutions were replaced daily. At the end of the period of exposure, the length of the longest root of each bulb was measured. Statistical analysis was performed using ANOVA complemented with the Student-Newman-Keuse and Dunnet tests. In this study p-values of less than $5 \%(\mathrm{P}<0.05)$ were considered to be statistically significant. All results were expressed as mean \pm standard deviation.

\section{Plasmid DNA cleavage activity in vitro}

Plasmid DNA pBSK II (Stratagene) was obtained and purified according to standard techniques (Ausubel et al., 1999). Briefly, Escherichia coli DH5 alpha cells were transformed with pBSK II. One colony was incubated overnight in $5 \mathrm{ml}$ of sterilized LB supplemented with $0,1 \mathrm{mg}$ $\mathrm{mL}^{-1}$ ampicilin medium at $37{ }^{\circ} \mathrm{C}$ with aeration, and $1 \mathrm{ml}$ of this suspension was inoculated in $300 \mathrm{ml}$ of LB supplemented with $0,1 \mathrm{mg} \mathrm{mL}^{-1}$ ampicilin medium and incubated for $8 \mathrm{~h}$ at $37{ }^{\circ} \mathrm{C}$ with aeration. Plasmid DNA from these cultures was purified using a Qiagen Plasmid Maxi Prep $\mathrm{Kit}^{\circledR}$. Spectrophotometric DNA quantification was carried out with a GE 2100 spectrophotometer, taking into account the rate of the $260 \mathrm{~nm}$ and $280 \mathrm{~nm}$ absorbances. The plasmid preparation was analyzed by gel electrophoresis to ensure that it consisted of approximately $90 \%$ intact supercoiled plasmid DNA. In order to evaluate the DNA cleavage activity, $600 \mathrm{ng}$ of the previously obtained supercoiled plasmid DNA pBSK II (FI) was incubated with either untreated water or water treated with calcinated coal mining waste in concentrations of 3.12 , $6.25,12.5,25.0$ and $50.0 \%$ at $\mathrm{pH} 7.5$ in a $25 \mathrm{mM}$ HEPES buffer ((N-[2-Hydroxyethyl]piperazine-N'-[2-ethanesulfonicacid]) SIGMA ${ }^{\circledR}$ ). Molecular grade water was used as negative control $(0 \%)$. All incubations were performed in triplicates with the same amount of DNA $(600 \mathrm{ng})$ at $37{ }^{\circ} \mathrm{C}$ for $12 \mathrm{~h}$. After this period, loading dye was added. Samples were submitted to agarose gel electrophoresis, photographed, and analyzed by densitometry with the Lab-Works ${ }^{\mathrm{TM}}$ Software v4.0 (UVP, Inc.) in order to evaluate the formation of intact (FI), open circular (FII) and linear (FIII) DNA forms.

\section{RESULTS AND DISCUSSION}

\section{Physicochemical parameters}

The results obtained in the physicochemical parameters demonstrate that untreated water had low $\mathrm{pH}$ and hight concentrations of aluminium, iron and manganese (Table 1), which is consistent with the literature (Lattuada et al., 2009). These parameters may be associated with water contamination by pollutants generated in coal mining, particularly acid mine drainage and carbonous-pyritic coal mining wastes, which both have high acidity and high concentration of metals (Laus et al., 2007; Geremias et al., 2012). It was observed that Point 1 was the most affected, due to its proximity to the mining areas (Table 1).

Treatment of water with calcinated coal mining wastes was able to promote the increase of $\mathrm{pH}$ and expressive removal of metals (Table 1). According to Geremias et al. (2008) these results may be due the presence of metal oxides in the calcinated waste $\left(\mathrm{SiO}_{2}, \mathrm{Al}_{2} \mathrm{O}_{3}\right.$ and $\left.\mathrm{Fe}_{2} \mathrm{O}_{3}\right)$ which are capable of promoting the adsorption of $\mathrm{H}_{3} \mathrm{O}^{+}$present in water, leading to a rise in $\mathrm{pH}$ with the consequent formation and precipitation of oxides and insoluble metal hydroxides. It is also possible that the metal ions are removed by adsorption onto oxides present in the waste, through interaction by complexation, the formation of ion pairs, ion exchange, electrostatic interaction, van der Waals forces, among other mechanisms (Wu et al., 2004; Topinkova et al., 2007).

These results are of great importance, since that the carbonou-pyritic coal mining waste not are recovered economically and promotes serious damage to the environment. Therefore, the use of calcinated waste has shown to represent an alternative method for water treatment contaminated by coal mining residues and/or other contaminants characterized by low $\mathrm{pH}$ values and by the presence of metals.

\section{Acute Toxicity in Artemia sp. and Daphnia magna}

It was observed in microcrustacean testing (Table 2) that the untreated water collected at Point 1 caused significant acute toxicity in Artemia sp. In samples from the remaining collection sites lethality was not evidenced in any of the concentrations tested, making the calculation of the $\mathrm{LC}_{50}$ impossible. In Daphnia magna testing, was observed a higher acute toxicity in Point 1 compared to Point 2 and Point 3 (Table 2). In the literature, it also has been shown a higher acute toxicity for Artemia sp. $\left(\mathrm{LC}_{50}=2.5 \%\right)$ when exposed to river

Table 1 - pH and concentrations of metals in untreated water and in water treated with calcinated coal mining waste.

\begin{tabular}{lcccccc}
\hline Parameters & \multicolumn{2}{c}{ Point 1 } & \multicolumn{2}{c}{ Point 2 } & \multicolumn{2}{c}{ Point 3 } \\
\hline & Untreated & Treated & Untreated & Treated & Untreated & Treated \\
\hline $\mathrm{pH}$ & 2.6 & 7.4 & 3.5 & 8.1 & 4.1 & 7.9 \\
$\mathrm{Al}\left(\mathrm{mg} \mathrm{L}^{-1}\right)$ & 54.0 & 1.0 & 6.2 & 1.1 & 3.5 & 1.0 \\
$\mathrm{Fe}\left(\mathrm{mg} \mathrm{L}^{-1}\right)$ & 26.0 & 0.2 & 0.8 & 0.2 & 0.3 & 0.2 \\
$\mathrm{Mn}\left(\mathrm{mg} \mathrm{L}^{-1}\right)$ & 3.0 & 1.4 & 0.6 & 0.3 & 0.6 & 0.6 \\
\hline
\end{tabular}


Table 2 - Acute toxicity (LC 50\%) in Artemia sp. and Daphnia magna exposed to untreated water and in water treated with calcinated coal mining waste.

\begin{tabular}{lcccccc}
\hline & \multicolumn{2}{c}{ Point 1 } & \multicolumn{2}{c}{ Point 2 } & \multicolumn{2}{c}{ Point 3 } \\
\hline & Untreated & Treated & Untreated & Treated & Untreated & Treated \\
\hline $\begin{array}{l}\text { Artemia } \\
\text { sp. }\end{array}$ & 4.4 & nt & nt & nt & nt & nt \\
$\begin{array}{l}\text { D. } \\
\text { magna }\end{array}$ & 6.2 & nt & 70.7 & nt & 73.4 & nt \\
\hline
\end{tabular}

$\mathrm{nt}=$ no acute toxicit

water affected by coal mining effluents. Similar results were also described for Daphnia magna $\left(\mathrm{LC}_{50}=3.68 \%\right)$ exposed to acid mine drainage. Autors suggest that the toxicity can be due to the low $\mathrm{pH}$ level $(<3,0)$ high concentration metals, such as, iron, manganese, zinc, copper and lead present on the tested samples (Geremias et al., 2003; Geremias et al., 2008).

It has been suggested that aquatic environments characterized by low $\mathrm{pH}$ and high metal concentrations cause respiratory and osmoregulatory distress, mutagenic and carcinogenic processes and even the death of the exposed biota (Ridge \& Seif, 1998). Therefore, highly toxic effects observed microcrustaceans exposed to water at Point 1 could be associated with higher acidity and concentration of metals in solution.

In our studies it was found that after the water treatment with calcinated waste, no acute toxicity was found in either organism at any of the collection points at previously tested concentrations. This result can be attributed to the $\mathrm{pH}$ neutralization together with the removal of the metals present in water.

\section{Allium cepa L. sub-chronic toxicity}

In $A$ cepa's sub-chronic toxicity, it was observed that the untreated water collected from three different points promoted significant inhibition of root growth when compared to the negative control group and to respective treated groups (Figure 1). As in the results obtained with microcrustacean testing, Point 1 showed more significant toxic effects in which we observe complete inhibition of growth. The literature has also described toxicity in Allium cepa $\mathrm{L}$. exposed to effluents containing metals such as $\mathrm{Fe}, \mathrm{Mn}, \mathrm{Cd}, \mathrm{Pb}, \mathrm{Ni}, \mathrm{Al}, \mathrm{Cu}$ and $\mathrm{Zn}$, with observable root growth inhibition (Palacio et al., 2005; Srivastava et al., 2005; Bortolotto et al., 2009).

The mechanisms involved in inhibition of the growth of the roots exposed to metal are not well established. It is suggested that this phytotoxic effect is related to the capacity of metals to accumulate in and interact with specific sites located in the cell wall, plasma membrane and in the cell nucleus (Dovgaliuk et al., 2001). As a consequence, several physiological, biochemical and molecular chain reactions could be triggered in the cell. Among these are: changes in the flow of water and nutrients; alteration in the calcium homeostasis, compromised cellular signaling events and disturbances to both the cell cycle and mitotic activity of meristematic cells. These effects could yield results which inhibit the growth of the plant's tissues, including its roots (Dovgaliuk et al., 2001; Boscolo et al., 2003; Ledislav et al., 2006; Glińska et al., 2007; Ezaki et al., 2008). However, plants might react against exposure to metals via a reduction in the fluid absorption, accumulation of metals in extracellular constituents, extraction of metals by exudates, secretion of metals in the meristems in the form of organic anions, compartmentalization of metals in vacuoles, complexation of metals with biomolecules, changes in the composition of lipid membrane to restore their properties and physical-chemical activation of metabolic pathways involved in the repair of damage and detoxification of xenobiotics (Clemens, 2006; Lei et al., 2007; Ezaki et al., 2008).

Therefore, the toxicity in A. cepa evidenced in our studies may be associated with the bioaccumulation of metals and the impairment of the protective mechanisms of the plant. The treatment of waters with calcinated waste promoted the reduction of toxic effects on $A$. серa and this result can be attributed to the increase in the $\mathrm{pH}$ and expressive removal of metals.

\section{Plasmid DNA cleavage activity}

The results of cleavage of plasmid DNA exposed to the samples collected at three points of the Urussanga River before and after treatment with calcinated waste are shown in Figure 2, in the form of pictures of the electrophoresis gels and plots of the percentage of DNA in its intact form (FI) versus concentration of the samples. The electrophoretic


Figure 1 - Inhibition of root growth in Allium cepa L. exposed to water from point 1 (A), point 2 (B) and point 3 (C). (a ) and (b) represents significant difference when compared to the negative control (mineral water) and treated sample, respectively. $\left({ }^{*} \mathrm{p}<0.05 ; * * \mathrm{p}<0.01 ; * * * \mathrm{p}<0.001\right)$. 
profile evidences that in untreated water samples there was DNA fragmentation at all collection points in every tested concentration. It was found that collection Point 1 showed greater potential for damage, since there was complete fragmentation of the DNA at all concentration with no visualization of any of the DNA's three forms. As for the remaining data collection points, complete fragmentation of DNA was shown at concentrations higher than $12.5 \%$, so that at lower values forms FI (intact) and FII (simple breaks) were still present. Lingard et al. (2005) also observed cleavage of plasmid DNA promoted by particulate material containing trace metals $\mathrm{Cr}, \mathrm{Cu}, \mathrm{Fe}, \mathrm{Mn}, \mathrm{Ni}$ and $\mathrm{Zn}$. The genotoxic effect observed could be associated with the presence of metals in water which are involved in the generation of reactive oxygen species able to catalyzing charge transfers and, therefore, of reacting with nucleic acids (Athanasios et al., 2000; Greenwell et al., 2002; Lingard et al., 2005; Gilli et al., 2007).

Our results showed that the treatment of waters with the calcinated waste promoted a significant decrease in DNA fragmentation, verified by the presence of intact forms in the three samples at all concentrations, as opposed to what was observed in untreated water. The reduction of DNA damage may be associated with the waste's capacity for promoting elevation of the $\mathrm{pH}$ to values close to neutrality, as well as its ability to reduce the concentration of metals in solution. In similarity to what is observed in the electrophoretic profile, the results obtained in the evaluation of intact DNA percentages revealed that the untreated water showed a high frequency of fragmentation when compared to water samples treated at all concentrations tested. This confirms the treatment's capacity for reducing damage to genetic material.

Therefore, all results obtained in our study indicated that the calcinated coal mining waste was effective in the treatment of water, since it was able to neutralize the acidity and removal metals from the solution, thereby attenuating their toxic and genotoxic effects. These results are of great relevance for the coal mining industry, which creates large amounts of carbonous-pyritic wastes that are associated with severe environmental damage, especially in aquatic environments.

\section{CONCLUSION}

The results obtained in this study demonstrated that the waters collected in the Urussanga river promoted expressive toxicity in Artemia sp., Daphnia magna and Allium cepa L. as well damage to plasmid DNA, possibly due to its acidity and the presence of metals in solution. The treatment of water using calcinated coal mining waste was effective in reducing these toxic effects, which could be associated with the removal through their adsorption on the surface of metal oxides. Therefore, mining-derived waste can be used as an alternate and low cost method of treating rivers contaminated by coal mining residues, offering an economic use for the waste and minimizing their environmental impact.

\section{ACKNOWLEDGMENTS}

This research was supported by grants from the Universidade do Extremo Sul Catarinense, Criciúma-SC, Brazil and Universidade Federal de Santa Catarina, Campus de Araranguá, Araranguá, Santa Catarina, Brazil.

\section{REFERENCES}

ABNT (Brazilian Association of Technical Standards),1993, NBR 12713. Water-acute toxicity test with Daphnia sp. (Crustacea, Cladocera). Rio de Janeiro.

ATHANASIOS, V., SALIKA, A. \& THEODOROPOULOU, A., 2000, Generation of hydroxyl radicals by urban suspended particulate air matter. The role of iron íons. Atmos Environ., 34:2379-2386.

AUSUBEL F.M.; BRENT R.; KINGSTON R.E.; MOORE D.D.; SEIDMAN J.G.; SMITH J.A. \& STRUHL K.,1999, Short protocols in molecular biology, Wiley, New York.

BENASSI, J.C., LAUS, R., GEREMIAS, R., LIMA, P.L., MENEZES, C.T., LARANJEIRA, M.C., WILHELM-FILHO, D., FÁVERE, V.T. \& PEDROSA, R.C., 2006, Evaluation of remediation of coal mining wastewater by chitosan microspheres using biomarkers. Arch Environ. Contam. Toxicol., 51:633-40.

BHARTI, S. \& BANERJEE, T.K, 2013, Bioassay analysis of efficacy of phytoremediation in decontamination of coal mine effluent.
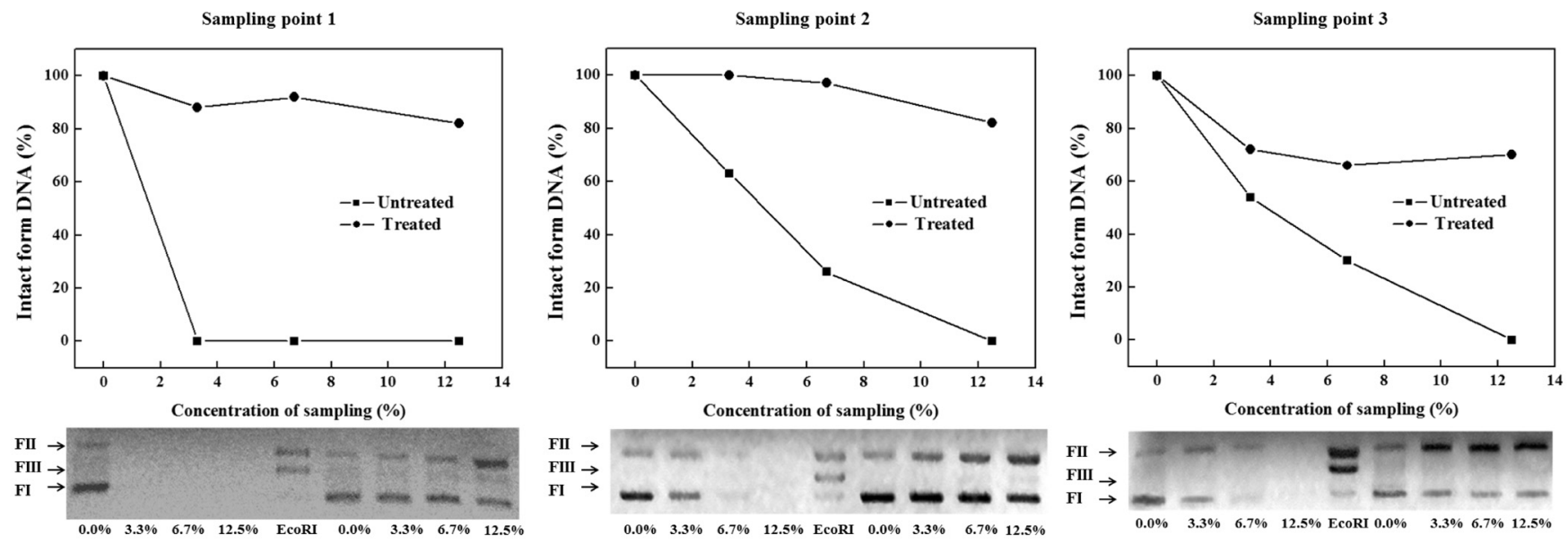

Figure 2 - Fragmentation of plasmid DNA. 
Environ. Toxicol. Pharmacol., 92:312-319. http://dx.doi.org/doi: 10.1016/j.ecoenv.2013.03.004.

BITAR, O.Y., Rehabilitation of degraded areas in metropolitan region of São Paulo, Brazil, 1997, Tesis Doctoral. Mineral Engineering Polytechnic, University of São Paulo, São Paulo, Brazil.

BLODAU, C., 2006, A review of acidity generation and consumption in acidic coal mine lakes and their watersheds. Sci. Total Environ., 369:307-332. http://dx.doi.org/doi:10.1016/j. scitotenv.2006.05.004

BORTOLOTTO, T.; BERTOLDO, J.B.; SILVEIRA, F.Z.; DEFAVERI, T. M.; SILVANO, J. \& PICH, C.T., 2009, Evaluation of the toxic and genotoxic potential of landfill leachates using bioassays. Environ. Toxicol. Pharmacol., 28:288-293.http:// dx.doi.org/doi: 10.1016/j.etap.2009.05.007.

BOSCOLO, P.R.S.; MENOSSI, M. \& JORGE, R.A., 2003, Aluminum induced oxidative stress in maize. Phytochemistry, 62:181-189.

BURGER, J.; FOSSIB, C.; MCCLELLAN-GREENC, P. \& ORLANDOD, E.F., 2007, Methodologies, bioindicators, and biomarkers for assessing gender-related differences in wildlife exposed to environmental chemicals. Environ. Res. J., 104:135152. http://dx.doi.org/doi:10.1016/j.envres.2006.08.002.

CLEMENS, S., 2006, Toxic metal accumulation, responses to exposure and mechanisms of tolerance in plants. Biochimie, 88:1707-1719. http://dx.doi.org/doi:10.1016/j.biochi.2006.07.003.

DOVGALIUK, A.L.; KALINIAK, T.B. \& BLIUM, I.A.B., 2001, Cytogenetic effects of toxic metal salts on apical meristem cells os Allium cepa L. seed roods. Tsitol. Genet., 35:3-10.EZAKI, B.; NAGAO, E.; YAMAMOTO, Y.; NAKASHIMAS, S. \& ENOMOTO, T., 2008, Wild plants, Andropogon virginicus L. and Miscanthus sinensis Anders, are tolerant to multiple stresses including aluminum, heavy metals and oxidative stresses. Plant Cell. Rep., 27:951-961. http://dx.doi.org/doi: 10.1007/s00299007-0503-8.

FATIMA, R.A. \& AHMAD, M., 2006, Allium cepa EROD as a potential biomarker for the presence of certain pesticids in walter. Chemosphere, 62:527-537. http://dx.doi.org/doi:10.1016/j. chemosphere.2005.06.032.

GEREMIAS, R., BORTOLOTTO, T., WILHELM-FILHO, D., PEDROSA, R.C.\& FÁVERE, V.T., 2012, Efficacy assessment of acid mine drainage treatment with coal mining waste using Allium cepa L. as a bioindicator. Ecotoxicol. Environ. Saf., 79:116-121. http://dx.doi.org/doi: 10.1016/j.ecoenv.2011.12.010.

GEREMIAS, R., LAUS, R., MACAN, J.M., PEDROSA, R.C., LARANJEIRA, M.C.M., SILVANO, J. \& FAVERE, V.T., 2008, Use of coal mining waste for the removal of acidity and metal ions $\mathrm{Al}$ (III), Fe (III) and $\mathrm{Mn}$ (II) in acid mine drainage. Environ Technol., 29:863-886. http://dx.doi.org/ doi:10.1080/09593330802015409.

GEREMIAS, R.; PEDROSA, R.C.; BENASSI, J.C.; FÁVERE, V.T.; STOLBERG, J.; MENEZES, C.T.B. \& LARANJEIRA, M.C., 2003, Remediation of coal mining wastewaters using chitosan microspheres. Environ. Technol., 24: 1509-1515.

GILlI, G.; TRAVERSI, D.; ROVERE, R.; PIGNATA, C. \& SCHILIRÒ, T., 2007, Chemical characteristics and mutagenic activity of PM10 in Torino, a Northern Italian City. Sci Total Environ, 385:97-107. http://dx.doi.org/doi:10.1016/j. scitotenv.2007.07.006.

GLIŃSKA, S.; BARTCZAK, M.; OLEKSIAK, S.; WOLSKA, A.; GABARA, B.; POSMYK, M. \& JANAS, K., 2007, Effects of anthocyanin-rich extract from red cabbage leaves on meristematic cells of Allium cepa L. roots treated with heavy metals. Ecotoxicol. Environ. Saf., 68:343-50. http://dx.doi.org/ doi:10.1016/j.ecoenv.2007.02.004
GREENWELL, L.L.; MORENO, T.; JONES, T.P. \& RICHARDS, R.J., 2002, Particle-induced oxidative damage is ameliorated by pulmonary antioxidants. Free Radic Biol Med., 32: 898-905.

HAMILTON M.A.; RUSSO R.C. \& THURSTON R.V., 1977, Trimmed Spearman-Karber method for estimating median lethal concentrations in toxicity bioassays. Environ. Sci. Technol., 11:714-719.

LATTUADA, R.M.; MENEZES, C.T.; PAVEI, P.T.; PERALBA, M.C. \& SANTOS, J.H., 2009, Determination of metals by total reflection X-ray fluorescence and evaluation of toxicity of a river impacted by coal mining in the south of Brazil. J Hazard Mater., 163:531-537. http://dx.doi.org/doi:10.1016/j. jhazmat.2008.07.003.

LAUS, R.; GEREMIAS, R.; VASCONCELOS, H.L.; LARANJEIRA, M.C.M. \& FÁVERE, V.T., 2007, Reduction of acidity and removal of metal ions from coal mining effluents using chitosan microspheres. J. Hazard Mater., 149:471-474. http://dx.doi.org/ doi:10.1016/j.jhazmat.2007.04.012.

LEDISLAV, T.; JANA, H.; IGOR, M.; MARTA, S. \& BEATA, S., 2006, Aluminum-induced drought and oxidative stress in barley roots. J. Plant Physiol., 163:781-784. http://dx.doi.org/ doi:10.1016/j.jplph.2005.08.012.

LEI, Y.; KORPELAINEN, H. \& CHUNYANG, L., 2007, Physiological and biochemical responses to high $\mathrm{Mn}$ concentrations in two contrasting Populus cathayana populations. Chemosfere, 68:686-94. http://dx.doi.org/doi:10.1016/j. chemosphere.2007.01.066.

LINGARD, J.J.N.; TOMLIN, A.S.; CLARKE, A.G.; HEALE, K..; HAY, A.W.M.; WILD, C.P. \& ROUTLEDGE, M., 2005, A study of trace metal concentration of urban airborne particulate matter and its role in free radical activity as measured by plasmid strand break assay. Atmos Environ., 39: 2377-2384. http://dx.doi.org/ doi:10.1016/j.atmosenv.2004.05.063.

MADZIVIREA, G.; GITARI, W.M.; VADAPALLI, V.R. K..; OJUMUD, T.V. \& PETRIKA L.F., 2011, Fate of sulphate removed during the treatment of circumneutral mine water and acid mine drainage with coal fly ash: Modelling and experimental approach. Miner.Eng., 24:1467-1477. http://dx.doi.org/ doi:10.1016/j.mineng.2011.07.009.

MARTINS, J.; TELES, L.O. \& VASCONCELO V., 2007, Assays with Daphnia magna and Danio rerio as alert systems in aquatic toxicology. Environ. Int., 33:414-425. http://dx.doi.org/ doi:10.1016/j.envint.2006.12.006.

MEYER, B.N.; FERRIGNI, N.R.; PUTNAM, J.E.; JACOBSEN, L.B.; NICHOLS, D.E. \& MCLAUGHLIN, J.L., 1982, Brine shrimp: a convenient general bioassay for active plant constituents. Planta Med., 45:31-34.

MITTEREGGER-JÚNIOR, H.; FERRAZ-DIAS，J.; LÚCIAYONEMA, M.; ARENZONA, A.; SILVA, J. \& PEGASHENRIQUES, J. A., 2006, Avaliação das Atividades Tóxicas e Mutagênicas da Água e do Sedimento do Arroio Estância Velha, Região Coureira-calçadista, Utilizando Allium cepa. J. Braz. Soc. Ecotoxicol., 1:147-151. http://dx.doi.org/doi:10.5132/ jbse.2006.02.011.

NETTO, E.; MADEIRA, R.A.;SILVEIRA, F.Z.; FIORI, M.A.; ANGIOLETO, E.; PICH, C.T. \& GEREMIAS, R., 2013, Evaluation of the toxic and genotoxic potential of acid mine drainage using physicochemical parameters and bioassays. Environ. Toxicol. Pharmacol., 35:511-516. http://dx.doi.org/doi: 10.1016/j.etap.2013.02.007.

NUNES, B.S.; CARVALHO, F.D.; GUILHERMINO, L.M. \& VAN STAPPEN, V., 2006, Use of the genus Artemia in ecotoxicity testing. Environ. Pollut., 144:453-462. http://dx.doi.org/ doi:10.1016/j.envpol.2005.12.037. 
PALACIO, S.M.; ESPINOZA-QUIÑONES, F.R.; GALANTE, R.M.; ZENATTI, D.C.; SEOLATTO, A.A.; LORENZ, E.K.; ZACARKIM, C. E.; ROSSI, N.; RIZZUTTO, M.A. \& TABACNIKS, M.H., 2005, Correlation between heavy metal ions (copper, zinc, lead) concentrations and root length of Allium cepa L. in polluted river water. Braz. Arch. Biol. Technol., 48:191196. http://dx.doi.org/10.1590/S1516-89132005000400024.

PIMENTEL, M. F.; SILVA JÚNIOR, F. C. G.; SANTAELLA, S. T. \& LOTUFO, L. V. C., 2011, O Uso de Artemia sp. como organismo-teste para avaliação da toxicidade das águas residuárias do beneficiamento da castanha de caju antes e após tratamento em reator biológico experimental. J. Braz. Soc. Ecotoxicol., 6:15-22. http://dx.doi.org/doi: 10.5132/jbse.2011.01.003.

RIDGE, T. \& SEIF, J.M., 1998, Coal mine drainage predicition an pollution prevention in Pennsylvania. Pennsylvania: Pennsylvania Department of Environmental Protection, 398 p.

SAURABH, C.; CHAUHANA, L.K.S.; MURTHYB, R.C.; SAXENA, P.N.; PANDEC, P.N. \& GUPTA S.K., 2005,
Comparative biomonitoring of leachates from hazardous solid waste of two industries using Allium test. Sci. Total Environ., $347: 46-52$.

SREEDHARA A. \& COWAN J A., 2001, Catalytic hydrolisys of DNA by metal íons and complexes. J. Biol.Inorg.Chem., 6:337347. http://dx.doi.org/doi:10.1016/j.scitotenv.2005.01.002.

SRIVASTAVA, R.; KUMAR, D. \& GUPTA, S.K., 2002, Bioremediation of municipal sludge by vermitechnology and toxicity assessment by Allium cepa. Bioresour. Technol., 96:186771. http://dx.doi.org/doi:10.1016/j.biortech.2005.01.029.

TOPINKOVA, B.; NESETRIL, K.; DATEL, J.; NOL, O. \& HOSL, P., 2007, Geochemical heterogeneity and isotope geochemistry of natural attenuation processes in a gasoline-contaminated aquifer at the Hnevice site, Czech Republic. Hydrogeol. J., 15:961-976.

WU, C.H.; LIN, C.F. \& CHEN, W.R., 2004, Regeneration and reuse of water treatment plant sludge: adsorbent for cations. J. Environ. Sci. Health A. Tox. Hazard Subst., 39:717-28. 